\title{
Taraxasterol inhibits TGF- $\beta 1$-induced proliferation and migration of airway smooth muscle cells through regulating the p38/STAT3 signaling pathway
}

\author{
Zihong SHAN ${ }^{1}$, Qingqing $\mathrm{LI}^{1}{ }^{(D)}$, Shuying WANG ${ }^{1}$, Yayun QIAN ${ }^{1}$, Haibo Li ${ }^{1 *}$
}

\begin{abstract}
Childhood asthma is a common chronic airway disease, and its severe form remains a challenging. Taraxasterol, a pentacyclic-triterpene isolated from Taraxacum officinale, has been shown to have anti-allergic property. However, the effects of taraxasterol on the proliferation and migration of airway smooth muscle cells (ASMCs) and the involved mechanisms remain unclear. Thus, the purpose of the present study was to investigate the functional role and potential molecular mechanism of taraxasterol in TGF- $\beta 1$-induced ASMC proliferation and migration. Our results showed that taraxasterol significantly suppressed the transforming growth factor $\beta 1$ (TGF- $\beta 1$ )-induced proliferation and migration of ASMCs. In addition, exposure of ASMCs to taraxasterol dramatically increased the expressions of contractile markers smooth muscle $\alpha$-actin ( $\alpha$-SMA) and myocardin, whereas expressions of extracellular matrix (ECM) proteins type I collagen (Col I) and fibronectin were reduced in TGF- $\beta 1$-stimulate ASMCs. Further studies revealed that taraxasterol suppressed the phosphorylation of p38 and signal transducer and activator of transcription 3 (STAT3) in TGF- $\beta 1$-stimualted ASMCs. Notably, p38 MAPK agonist P79350 reversed the protective effects of taraxasterol on ASMCs. In conclusion, these findings indicated that taraxasterol inhibits TGF- $\beta 1$-induced proliferation and migration of ASMCs through inactivation of p38/STAT3 signaling pathway.
\end{abstract}

Keywords: asthma; taraxasterol; airway smooth muscle cells (ASMCs); p38/STAT3 pathway.

Practical Application: Taraxasterol may be a promising therapeutic candidate for the treatment of asthma.

\section{Introduction}

Asthma is a heterogeneous clinical syndrome characterized by inflammation, reversible airway obstruction, hyperresponsiveness, and airway remodeling. It has increased in prevalence over the past 30 years and currently affects 235 million people worldwide (Toop, 1985). Airway smooth muscle (ASM) plays crucial roles in airway remodeling during asthma pathogenesis. Airway smooth muscle cells (ASMCs) are key cell type in the pathophysiology of airway remodeling because of their multifunctional properties and intrinsic plasticity (Black et al., 2003). During airway remodeling, ASM proliferation contributes towards increased ASM mass, which tends to increase airway narrowing and airflow obstruction. A growing body of evidence indicates that ASMC migration toward the airway epithelium in response to inflammatory mediators such as transforming growth factor $\beta 1$ (TGF- $\beta 1$ ), thereby promoting airway remodeling (Chen et al., 2015; Cheng et al., 2018).

Taraxasterol, a pentacyclic-triterpene isolated from Taraxacum officinale, has been shown to have anti-inflammatory, anti-arthritic, neuro-protective and anti-tumor effects (Bao et al., 2018; Liu et al., 2018; Wang et al., 2016). A study by Chen et al. (2019) reported that taraxasterol attenuates inflammatory response in interleukin (IL)-1 $\beta$-stimulated human fibroblast-like synoviocytes rheumatoid arthritis (HFLS-RA) in vitro and collagen-induced arthritis (CIA) mice in vivo (Chen et al., 2019). In addition, taraxasterol has been reported to possess anti-allergic property. Liu et al. (2013) reported that taraxasterol reduces the production of Th2 cytokine IL-4, IL-5, IL-13 in bronchoalveolar lavage fluid (BALF) and ovalbumin (OVA)-specific IgE in sera, as well as and suppresses airway hyperresponsiveness in OVA-induced allergic asthma in mice (Liu et al., 2013). However, the effects of taraxasterol on the cell proliferation and migration of TGF- $\beta 1$-induced ASMCs and the involved mechanisms remain unclear. Thus, the purpose of the present study was to investigate the functional role and potential molecular mechanism of taraxasterol in TGF- $\beta 1$-induced ASMC proliferation and migration.

\section{Materials and methods}

\subsection{Cell culture}

Human ASMCs line (American Type Culture Collection, ATCC, Manassas, VA, USA) were grown in Dulbecco's Modified Eagle's Medium (DMEM; Gibco Laboratories, Carlsbad, CA, USA) supplemented with $10 \%$ fetal bovine serum (Gibco) and $1 \%$ penicillin/streptomycin (Sigma-Aldrich, St. Louis, MO, USA). ASMCs were maintained in a humidified atmosphere of $5 \% \mathrm{CO}_{2}$ at $37^{\circ} \mathrm{C}$.

\subsection{Cell cytotoxicity assay}

Cell cytotoxicity was detected by MTT assay. Briefly, ASMCs were incubated with series concentrations of taraxasterol 
$(0,5,10,20,40 \mu \mathrm{M})$ for $48 \mathrm{~h}$. Then, $20 \mu \mathrm{l} 5 \mathrm{mg} / \mathrm{ml}$ MTT solution was added and incubated for $4 \mathrm{~h}$ at $37^{\circ} \mathrm{C}$. Afterwards, the medium was removed and $200 \mu \mathrm{l}$ dimethylsulfoxide (DMSO) was added to dissolve the formazan crystals. The absorbance was read at $490 \mathrm{~nm}$ using a microplate reader (Bio-Tek, Winooski, VT, USA).

\subsection{Cell proliferation assay}

Cell proliferation was measured using the Cell Counting Kit-8 assay (CCK-8; Dojindo, Kumamoto, Japan). Briefly, ASMCs $\left(1 \times 10^{4}\right.$ cells/well $)$ were seeded in 96 -well plates for $24 \mathrm{~h}$. Then, cells were pretreated with various concentrations of taraxasterol $(5,10,20 \mu \mathrm{M})$ for $1 \mathrm{~h}$, followed by incubation with TGF- $\beta 1$ $(10 \mathrm{ng} / \mathrm{ml})$ for $48 \mathrm{~h}$. Finally, $10 \mu \mathrm{l}$ of CCK-8 reagent (Dojindo, Kumamoto, Japan) was added to each well and incubated for $2 \mathrm{~h}$. The absorbance at a wavelength of $450 \mathrm{~nm}$ was measured using a spectrophotometer (Bio-Rad Laboratories, Hercules, CA, USA).

\subsection{Transwell migration assay}

Cell migration was detected using Transwell culture chambers (Corning Life Sciences, Corning, NY, USA). Briefly, the treated ASMCs $\left(1 \times 10^{4}\right.$ cells/well $)$ were suspended in serum-free medium and plated in the upper chamber, and $600 \mu \mathrm{L}$ DMEM medium supplemented with $10 \%$ FBS was added into the lower chamber. After $24 \mathrm{~h}$, the migrated cells on the lower side of the inserts were fixed, stained with $0.5 \%$ crystal violet for $30 \mathrm{~min}$ and counted under a microscope (Olympus, Tokyo, Japan).

\subsection{Quantitative real-time polymerase chain reaction (qRT-PCR)}

The total RNA was extracted from ASMCs using Trizol reagent (Invitrogen) according to the manufacturer's protocol. Then, $2 \mu \mathrm{g}$ of total RNA was reverse transcribed to cDNA using the Prime Script RT Master Mix (TaKaRa Bio, Shiga, Japan). The qRT-PCR was performed using the SYBR Select Master Mix (Applied Biosystems, Foster City, CA, USA) on the ABI7300 system (Applied Biosystems) according to the manufacturer's instructions. The primers were as follows: smooth muscle $\alpha$-actin (a-SMA), forward 5'-AGAGTTACGAGTTGCCTGATGG-3' and reverse 5'-GATGCTGTTGTAGGTGGTTTCA-3'; myocardin, forward 5'-AGGT AACACAGCCTCCATCCTA-3' and reverse 5'-TGGGTATCTTTGGGACTTTT TG-3'; type I collagen (Col I), forward 5'-GTCCTCCTGGTTCTCCTGGT-3' and reverse 5'-GACCGTTGAGTCCGTCTTTG-3'; fibronectin, forward 5'-GAAG TCGCAAGGAAACAAGC-3' and reverse 5'-GTAGGTGAACGGGAGGACAC-3'; $\beta$-actin, forward 5'-AGAAGGCTGGGGCTCATTTG-3' and reverse 5'-AGGGGCCATCCACAGTCTTC-3'.

\subsection{Western blot}

Total protein was extracted from ASMCs using RIPA lysis buffer (Beyotime). Equal amounts of protein $(30 \mu \mathrm{g})$ were loaded and by $12 \%$ SDS-PAGE and transferred to polyvinylidene difluoride (PVDF) membranes (Millipore, Billerica, MA, USA). The membranes were blocked in $5 \%$ non-fat milk for $1 \mathrm{~h}$ at room temperature and incubated with primary antibodies against a-SMA, myocardin, p38, p-p38, signal transducer and activator of transcription 3 (STAT3), p-STAT3, and $\beta$-actin (Abcam) at $4{ }^{\circ} \mathrm{C}$ overnight. After washing for three times, the membranes were incubated with secondary antibodies conjugated with horseradish peroxidase (Abcam) for $1 \mathrm{~h}$ at room temperature. Finally, immunoreactive proteins were visualized using an ECL reagent (Thermo Fisher Scientific).

\subsection{Enzyme-Linked Immunosorbent Assay (ELISA)}

After different treatments, the cell supernatants of ASMCs were collected for ELISA. The concentrations of Col I and fibronectin in cell supernatant were measured using the commercial Col I and fibronectin ELISA kits (R\&D Systems, Minneapolis, MN, USA) following the manufacturer's instructions.

\subsection{Statistical analysis}

All data were expressed as a mean \pm standard deviation (SD) from at least 3 independent experiments. Statistical analysis was carried out using one-way analysis of variance (ANOVA) followed by Bonferroni test for multiple groups, or student's- $t$ test between two groups (using SPSS 13.0 software; SPSS Inc., Chicago, USA). A p-value less than 0.05 indicated that the difference between groups was statistically significant.

\section{Results}

\subsection{Taraxasterol inhibits TGF- $\beta 1$-induced cell proliferation and migration in ASMCs}

We first investigated the cytotoxicity of taraxasterol in ASMCs. As shown in Figure 1A, $40 \mu \mathrm{M}$ taraxasterol had a significant effect on cell viability, however, the viability of ASMCs was unaffected by taraxasterol at concentrations of 5,10 and $20 \mu \mathrm{M}$. Therefore, 5-20 $\mu \mathrm{M}$ of taraxasterol was used in the following experiments. Next, we investigated the effects of taraxasterol on cell proliferation and migration in TGF- $\beta 1$-stimulated ASMCs. The results of CCK-8 assay indicated that TGF- $\beta 1$ treatment greatly promoted ASMCs proliferation, while this effect was attenuated by taraxasterol. Transwell migration assay showed that taraxasterol significantly suppressed TGF- $\beta 1$-induced cell migration in ASMCs (Figure 1C).

\subsection{Taraxasterol increased the expression of contractile phenotypic markers in TGF-ß1-stimulated ASMCs}

Then, we evaluated the effect of taraxasterol on the expressions of contractile phenotypic markers including $\alpha$-SMA and myocardin in TGF- $\beta 1$-stimulated ASMCs. As shown in Figure $2 \mathrm{~A}-\mathrm{C}$, TGF- $\beta 1$ treatment significantly reduced the expression of $\alpha$-SMA and myocardin at both mRNA and protein levels in ASMCs, whereas pre-incubation with taraxasterol significantly reversed the effects mediated by TGF- $\beta 1$, leading to significant increased the expression of $\alpha$-SMA and myocardin.

\subsection{Taraxasterol inhibits the expression of ECM proteins in TGF- $\beta 1$-stimulated ASMCs}

To further investigate the effect of taraxasterol on ECM accumulation in ASMCs, the levels of $\mathrm{Col} \mathrm{I}$ and fibronectin were measured. The results of qRT-PCR assay showed that the gene expression of $\mathrm{Col} \mathrm{I}$ and fibronectin was upregulated in ASMCs 


\section{A}

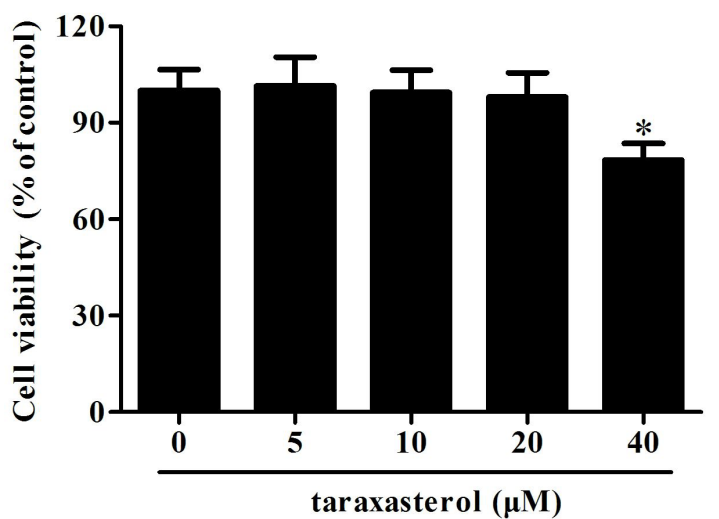

B

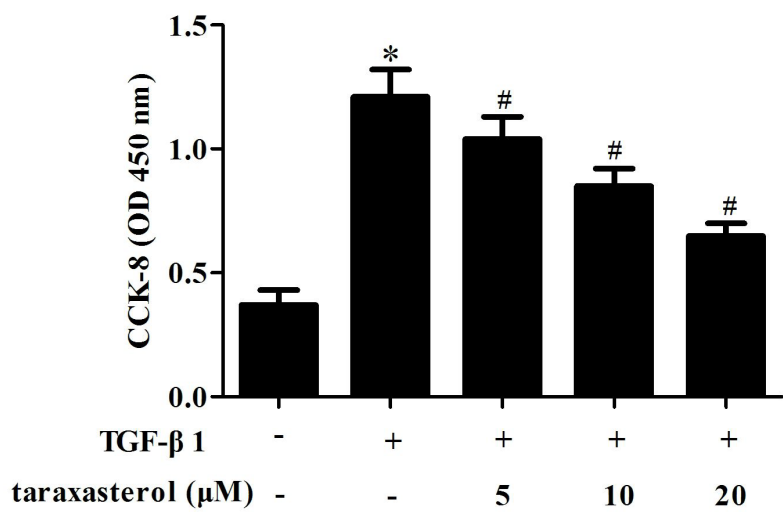

C

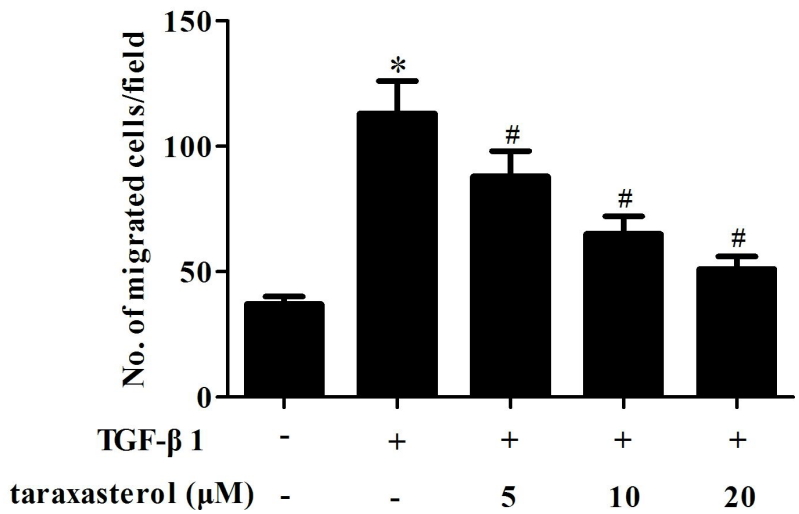

Figure 1. Taraxasterol inhibited TGF- $\beta 1$-induced ASMCs proliferation and migration. (A) ASMCs were incubated with series concentrations of taraxasterol $(0,5,10,20$ and $40 \mu \mathrm{M})$ for $48 \mathrm{~h}$; MTT assay was performed to evaluate cell viability; (B) ASMCs were pretreated with taraxasterol $(5,10$, or $20 \mu \mathrm{M})$ for $1 \mathrm{~h}$, and then incubated with TGF- $\beta 1$ $(10 \mathrm{ng} / \mathrm{ml})$ for 24; Cell proliferation was detected using CCK-8 assay; (C) Cell migration was measured using Transwell migration assay; ${ }^{*} p<0.05$ vs. control group; ${ }^{*} p<0.05$ vs. TGF- $\beta 1$ group.

exposed to TGF- $\beta 1$, while taraxasterol noticeably suppressed the induction. In addition, we performed ELISA to measure the production of Col I and fibronectin in supernatant and found that taraxasterol clearly inhibited the TGF- $\beta 1$-induced secretion of Col I and fibronectin in ASMCs (Figure 3C, D).

\subsection{Taraxasterol inhibits the activation of p38/STAT3 pathway in TGF- $\beta 1$-stimulated ASMCs}

In order to explore the underlying mechanism which is responsible for taraxasterol-mediated effect, we examined the effect of taraxasterol on p38/STAT3 pathway. As indicated in Figure 4, TGF- $\beta 1$ treatment markedly increased the levels of p-p38 and p-STAT3 in ASMCs. However, the activation of p38/STAT3 pathway caused by TGF- $\beta 1$ was reversed by taraxasterol.

\section{5 p38 MAPK agonist P79350 reversed the effects of taraxasterol on ASMCs proliferation and migration}

To confirm whether p38 MAPK pathway was involved in regulating taraxasterol -mediated protective effect, we examined the effect of p38 MAPK agonist P79350 on taraxasterol-regulated ASMCs proliferation and migration. The results indicated that P79350 significantly reversed the protective effects of taraxasterol against TGF- $\beta 1$-induced ASMCs proliferation and migration (Figure 5A, B).

\section{6 p38 MAPK agonist $P 79350$ reversed the effects of taraxasterol on contractile phenotypic markers and ECM proteins in TGF- $\beta 1$-induced ASMCs}

Then, we examined the effects of P79350 on taraxasterol-regulated contractile phenotypic markers and ECM proteins expression in TGF- $\beta 1$-induced ASMCs. As shown in Figures 6A-C, P79350 significantly reversed the protective effects of taraxasterol on $\alpha$-SMA and myocardin expressions, as well as $\mathrm{Col} I$ and fibronectin productions in TGF- $\beta 1$-stimulated ASMCs.

\section{Discussion}

In this study, we showed for the first time that taraxasterol significantly suppressed the TGF- $\beta 1$-induced proliferation and migration of ASMCs. In addition, taraxasterol increased the expression of contractile phenotypic markers and inhibited the expression of ECM proteins in TGF- $\beta 1$-stimulated ASMCs. Furthermore, taraxasterol prevented the activation of p38/STAT3 pathway in TGF- $\beta 1$-stimulated ASMCs.

Phenotype switching of ASMCs, defined as a reversible switching between contractile and proliferative phenotypes, plays a critical role in the process of airway remodeling (Sandford et al., 1998). The proliferating ASMCs have an increased proliferative capacity, more mitotically active, and express lesser amounts of contractile proteins such as smooth muscle myosin heavy chain (SM-MHC), myocardin and calponin (Halayko et al., 1996). Under normal conditions, ASMCs remain in a quiescent and non-migratory state. TGF- $\beta 1$ is one of the dimeric isoforms that has a prominent role in promoting the changes of ASMCs from a contractile phenotype to a pro-remodeling phenotype with proliferative, migrative and synthetic abilities (Zhu et al., 2015). Thus, we used TGF- $\beta 1$ to induce the phenotypic change of ASMCs. Our results showed that taraxasterol reversed the TGF- $\beta 1$-induced inhibition of the expression of contractile phenotypic markers in ASMCs.

ECM deposition in the airways is an important pathological manifestation of airway remodeling (Ambhore et al., 2019). 
A

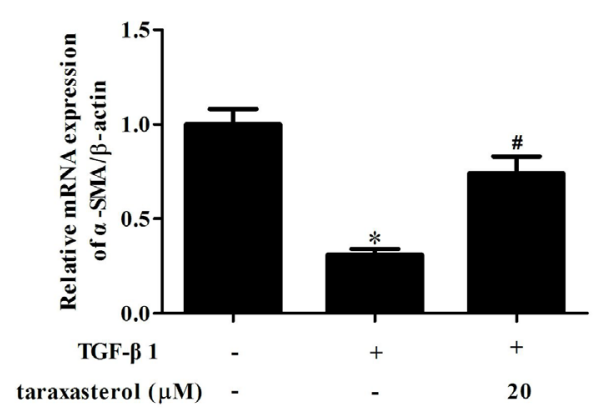

C

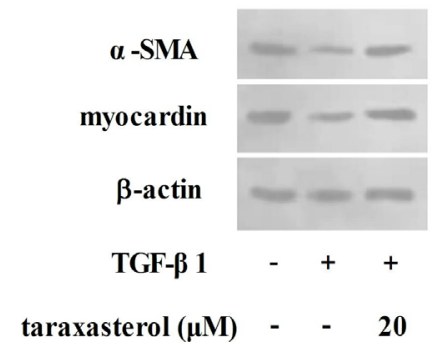

B

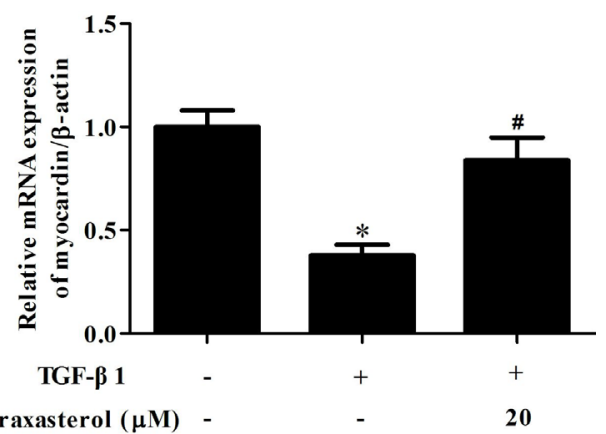

Figure 2. Taraxasterol reversed the TGF- $\beta 1$-induced inhibition of the expression of contractile phenotypic markers in ASMCs; ASMCs were pretreated with taraxasterol $(5,10$, or $20 \mu \mathrm{M})$ for $1 \mathrm{~h}$, and then incubated with TGF- $\beta 1(10 \mathrm{ng} / \mathrm{ml})$ for $24 \mathrm{~h}$; (A), (B) The mRNA expression levels of $\alpha$-SMA and myocardin were measured using qRT-PCR; (C) The protein expression levels of $\alpha$-SMA and myocardin were measured using western blot analysis; ${ }^{*} p<0.05$ vs. control group; ${ }^{*} p<0.05$ vs. TGF- $\beta 1$ group.

A

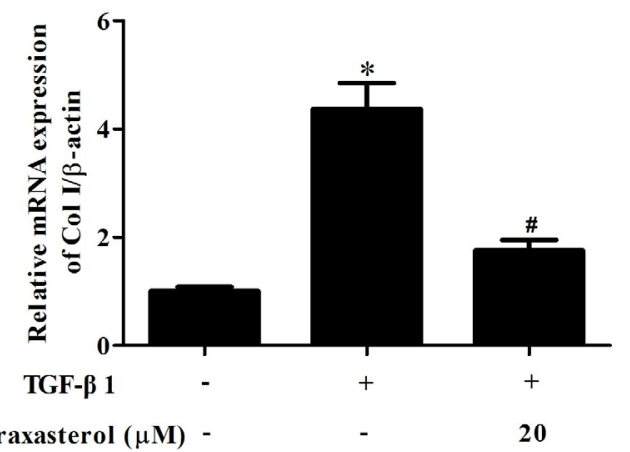

$\mathbf{C}$

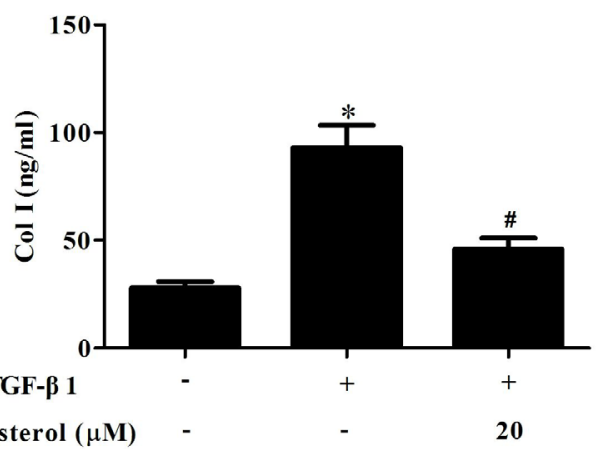

$\mathbf{B}$

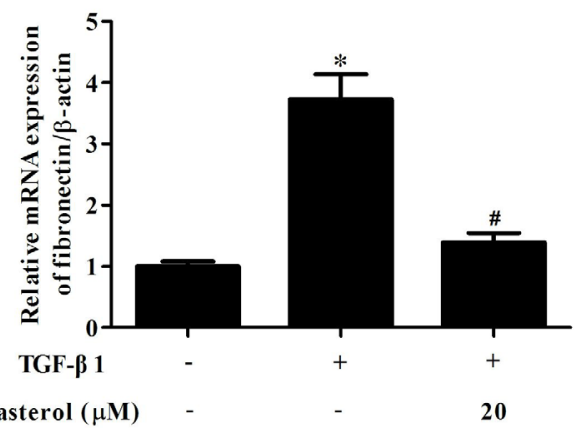

D

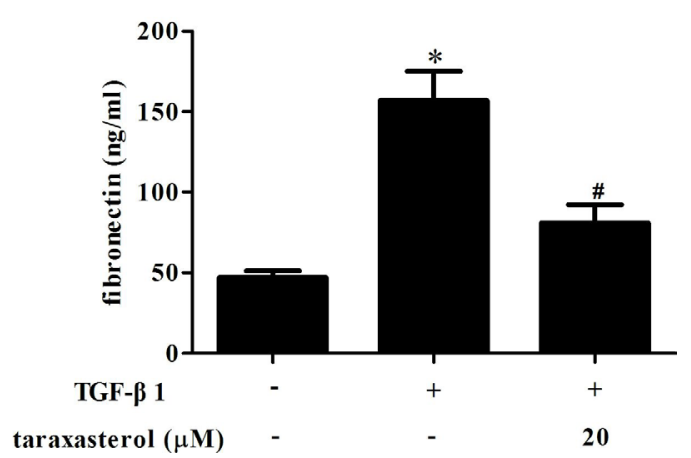

Figure 3. Taraxasterol suppressed Col I and fibronectin production in TGF- $\beta 1$-stimulated ASMCs; ASMCs were pretreated with taraxasterol $(5,10$, or $20 \mu \mathrm{M})$ for $1 \mathrm{~h}$, followed by incubation with TGF- $\beta 1(10 \mathrm{ng} / \mathrm{ml})$ for $24 \mathrm{~h}$; (A), (B) The mRNA expression levels of Col I and fibronectin were detected using qRT-PCR; (C), (D) The concentration of Col I and fibronectin in cell supernatants were determined using ELISA; ${ }^{*} p<0.05$ vs. control group; ${ }^{*} p<0.05$ vs. TGF- $\beta 1$ group. 
A
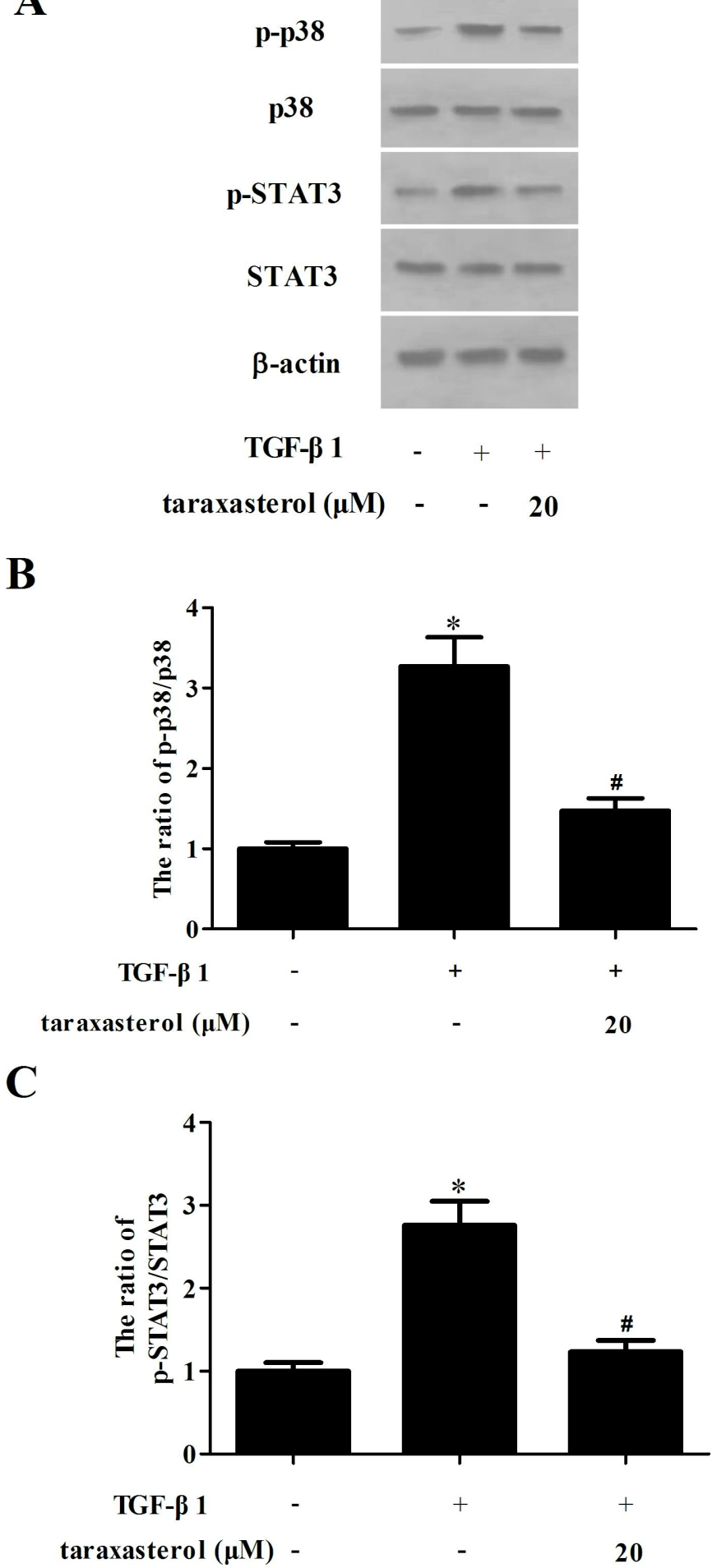

Figure 4. Taraxasterol prevented the activation of p38/STAT3 pathway in TGF- $\beta 1$-stimulated ASMCs; ASMCs were pretreated with taraxasterol $(5,10$, or $20 \mu \mathrm{M})$ for $1 \mathrm{~h}$, followed by incubation with TGF- $\beta 1(10 \mathrm{ng} / \mathrm{ml})$ for $1 \mathrm{~h}$; (A)-(C) The levels of p38, p-p38, STAT3, and p-STAT3 were evaluated using western blot; ${ }^{\star} p<0.05$ vs. control group; ${ }^{*} p<0.05$ vs. TGF- $\beta 1$ group.

Previous studies have shown that ECM proteins, in particular Col I and fibronectin, can alter non-asthmatic derived ASM cells towards a proliferative phenotype (Nishihara-Fujihara et al.,
A

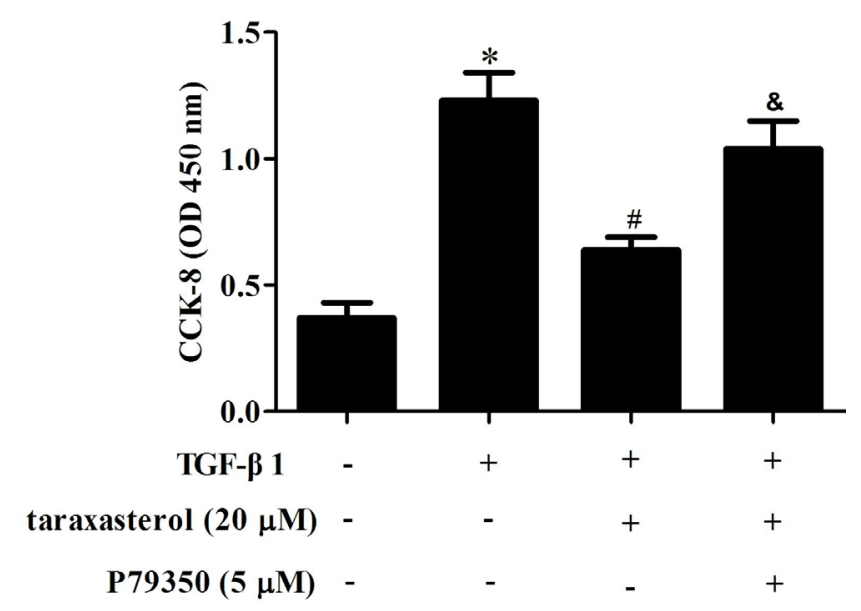

B

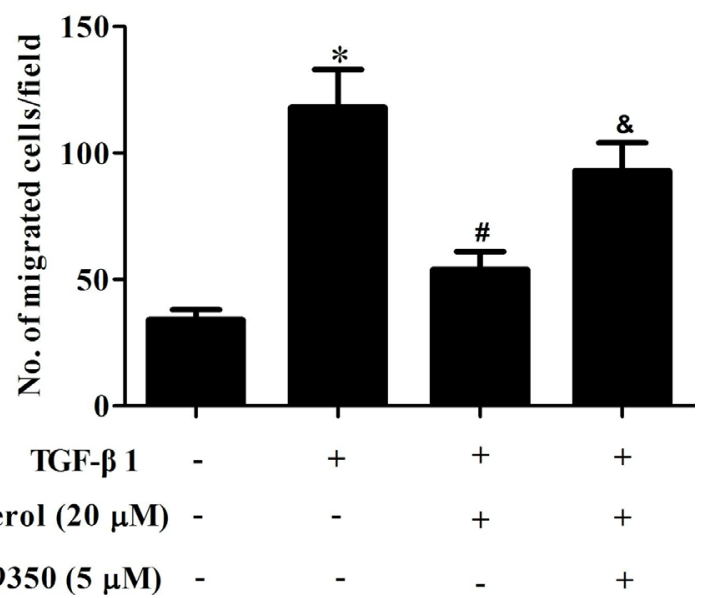

Figure 5. p38 MAPK agonist P79350 reversed the effects of taraxasterol on ASMCs proliferation and migration; ASMCs were treated with $20 \mu \mathrm{M}$ taraxasterol and P79350 (5 $\mu \mathrm{M})$ before TGF- $\beta 1$ treatment; (A) Cell proliferation was detected using the CCK- 8 assay; (B) Cell migration was measured using Transwell assay; ${ }^{*} p<0.05$ vs. control group; ${ }^{*} \mathrm{p}<0.05$ vs. TGF- $\beta 1$ group; ${ }^{\circledR} p<0.05$ vs. TGF- $\beta 1+$ taraxasterol group.

2010; Roberts \& Burke, 1998). In this study, we observed that taraxasterol inhibited the expression of Col I and fibronectin in TGF- $\beta 1$-stimulated ASMCs.

Emerging evidences suggest that the p38 MAPK signaling pathway is involved in regulating proliferation and migration of ASMCs (Fernandes et al., 2004; Quante et al., 2008; Willems-Widyastuti et al., 2013). Cao et al. (2018) reported that SB203580 (inhibitor of p-38) could inhibit the activation of p38, attenuate phosphorylation of STAT3, and decrease the expression of col I and $\alpha$-SMA in both human fibroblasts and airway tissue of OVA-challenged mice (Cao et al., 2018). In addition, STAT3 is an important signal transcription factor in JAK/STAT signaling pathway and is involved in cell proliferation, differentiation, metastasis and angiogenesis (Koning et al., 2000; Doucette et al., 2012; Wei et al., 2003). STAT3 was acted a key 


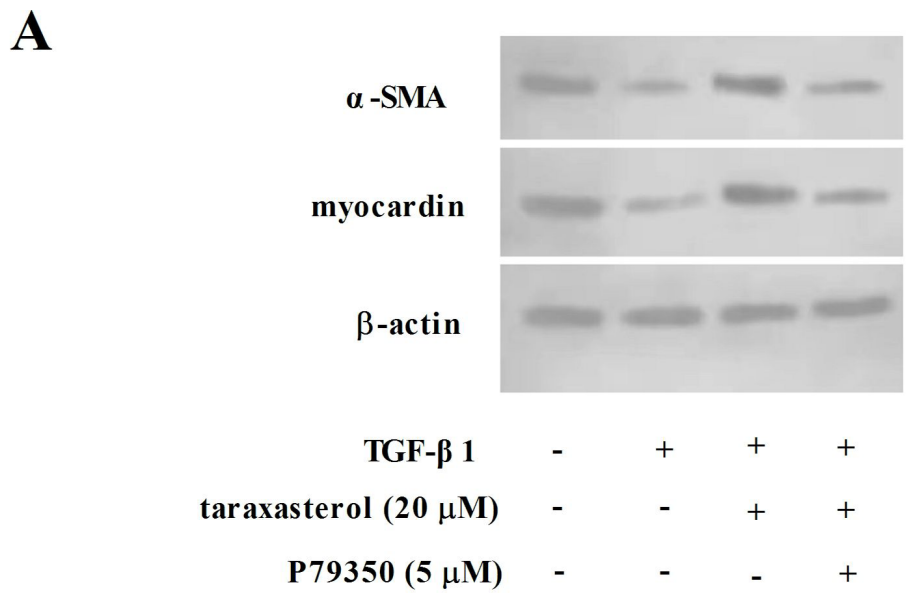

B

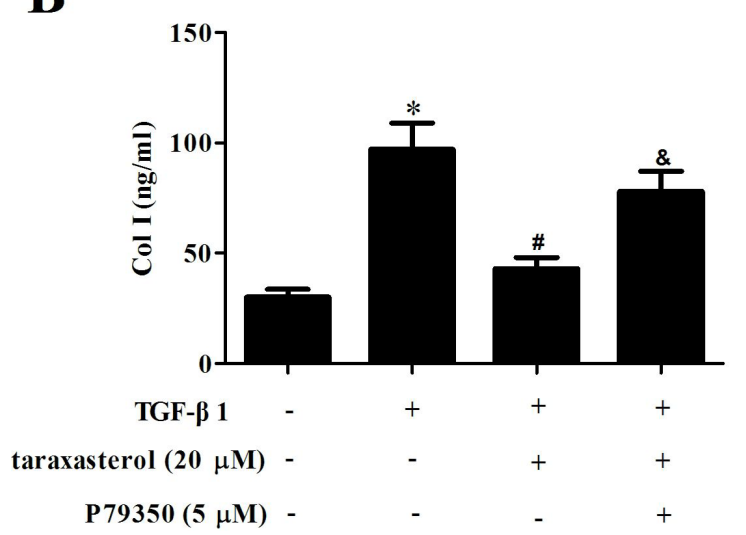

C

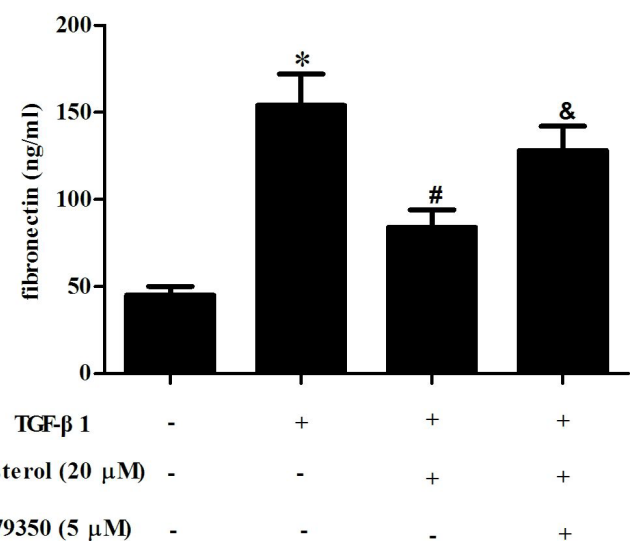

Figure 6. p38 MAPK agonist P79350 reversed the effects of taraxasterol on contractile phenotypic markers and ECM proteins in TGF- $\beta 1$-induced ASMCs; ASMCs were treated with $20 \mu \mathrm{M}$ taraxasterol and P79350 (5 $\mu \mathrm{M})$ before TGF- $\beta 1$ treatment; (A) The protein levels of contractile phenotypic markers including a-SMA and myocardin were measured using western blot; (B), (C) The production of Col I and fibronectin was measured using ELISA; ${ }^{\star} p<0.05$ vs. control group; ${ }^{*} p<0.05$ vs. TGF- $\beta 1$ group; ${ }^{\circledR} p<0.05$ vs. TGF- $\beta 1+$ taraxasterol group.

regulatory factor in airway remodeling (Litonjua et al., 2005; Redhu et al., 2013; Simeone-Penney et al., 2007). Previous studies showed that upregulation of STAT3 dramatically promoted the proliferation of human ASMCs, and STAT3 inhibitor greatly attenuated airway remodeling and lung inflammation in asthmatic mice (Gavino et al., 2016; Tang \& Luo, 2018). Therefore, we investigated whether taraxasterol could affect p38/STAT3 pathway in TGF- $\beta 1$-induced ASMCs. The results showed that taraxasterol inhibited the activation of p38/STAT3 signaling pathway caused by TGF- $\beta 1$ induction. And p38 MAPK agonist P79350 reversed the protective effects of taraxasterol on ASMCs.

In conclusion, these findings demonstrated that taraxasterol suppressed cell proliferation, migration, ECM accumulation, while elevated the expressions of contractile phenotypic markers in TGF- $\beta 1$-stimulated ASMCs. The effects of taraxasterol might be mediated by the inhibition of p38/STAT3 signaling pathway. Thus, taraxasterol may be a promising therapeutic candidate for the treatment of asthma.

\section{Conflict of interest}

The authors declare no conflicts of interest.

\section{References}

Ambhore, N. S., Kalidhindi, R., Pabelick, C. M., Hawse, J. R., Prakash, Y. S., \& Sathish, V. (2019). Differential estrogen-receptor activation regulates extracellular matrix deposition in human airway smooth muscle remodeling via NF- $\kappa$ B pathway. The FASEB Journal, 33(12), 13935-13950. http://dx.doi.org/10.1096/fj.201901340R. PMid:31638834.

Bao, T., Ke, Y., Wang, Y., Wang, W., Li, Y., Wang, Y., Kui, X., Zhou, Q., Zhou, H., Zhang, C., Zhou, D., Wang, L., \& Xiao, C. (2018). Taraxasterol suppresses the growth of human liver cancer by upregulating Hint 1 expression. Journal of Molecular Medicine, 96(7), 661-672. http:// dx.doi.org/10.1007/s00109-018-1652-7. PMid:29806073.

Black, J. L., Burgess, J. K., \& Johnson, P. R. (2003). Airway smooth muscle--its relationship to the extracellular matrix. Respiratory Physiology \& Neurobiology, 137(2-3), 339-346. http://dx.doi. org/10.1016/S1569-9048(03)00157-5. PMid:14516736.

Cao, L., Liu, F., Liu, Y., Liu, T., Wu, J., Zhao, J., Wang, J., Li, S., Xu, J., \& Dong, L. (2018). TSLP promotes asthmatic airway remodeling via p38-STAT3 signaling pathway in human lung fibroblast. Experimental Lung Research, 44(6), 288-301. http://dx.doi.org/10.1080/01902148 .2018.1536175. PMid:30428724.

Chen, J., Wu, W., Zhang, M., \& Chen, C. (2019). Taraxasterol suppresses inflammation in IL-1 $\beta$-induced rheumatoid arthritis fibroblastlike synoviocytes and rheumatoid arthritis progression in mice. 
International Immunopharmacology, 70, 274-283. http://dx.doi. org/10.1016/j.intimp.2019.02.029. PMid:30851708.

Chen, M., Shi, J., Lv, Z., Huang, L., Lin, X., Zhang, W., Liang, R., Li, Y., \& Jiang, S. (2015). Triptolide inhibits transforming growth factor- $\beta 1$-induced proliferation and migration of rat airway smooth muscle cells by suppressing nuclear factor- $\kappa \mathrm{B}$ but not extracellular signal-regulated kinase 1/2. Immunology, 144(3), 486-494. http:// dx.doi.org/10.1111/imm.12396.

Cheng, W., Yan, K., Chen, Y., Zhang, W., Ji, Z., \& Dang, C. (2018). ABCA1 inhibits PDGF-induced proliferation and migration of rat airway smooth muscle cell through blocking TLR2/NF-kappaB/ NFATc1 signaling. Journal of Cellular Biochemistry, 119(9), 73887396. http://dx.doi.org/10.1002/jcb.27046. PMid:29775222.

Doucette, T. A., Kong, L. Y., Yang, Y., Ferguson, S. D., Yang, J., Wei, J., Qiao, W., Fuller, G. N., Bhat, K. P., Aldape, K., Priebe, W., Bögler, O., Heimberger, A. B., \& Rao, G. (2012). Signal transducer and activator of transcription 3 promotes angiogenesis and drives malignant progression in glioma. Neuro-Oncology, 14(9), 1136-1145. http:// dx.doi.org/10.1093/neuonc/nos139. PMid:22753228.

Fernandes, D. J., Ravenhall, C. E., Harris, T., Tran, T., Vlahos, R., \& Stewart, A. G. (2004). Contribution of the p38MAPK signalling pathway to proliferation in human cultured airway smooth muscle cells is mitogen-specific. British Journal of Pharmacology, 142(7), 1182-1190. http://dx.doi.org/10.1038/sj.bjp.0705809. PMid:15249425.

Gavino, A. C., Nahmod, K., Bharadwaj, U., Makedonas, G., \& Tweardy, D. J. (2016). STAT3 inhibition prevents lung inflammation, remodeling, and accumulation of Th2 and Th17 cells in a murine asthma model. Allergy, 71(12), 1684-1692. http://dx.doi.org/10.1111/all.12937. PMid:27225906.

Halayko, A. J., Salari, H., Ma, X., \& Stephens, N. L. (1996). Markers of airway smooth muscle cell phenotype. The American Journal of Physiology, 270(6 Pt 1), L1040-L1051. PMid:8764231.

Koning, J. P., Soede-Bobok, A. A., Ward, A. C., Schelen, A. M., Antonissen, C., van Leeuwen, L. D., Löwenberg, B., \& Touw, I. P. (2000). STAT3-mediated differentiation and survival and of myeloid cells in response to granulocyte colony-stimulating factor: role for the cyclin-dependent kinase inhibitor p27(Kip1). Oncogene, 19(29), 3290-3298. http://dx.doi.org/10.1038/sj.onc.1203627. PMid:10918585.

Litonjua, A. A., Tantisira, K. G., Lake, S., Lazarus, R., Richter, B. G., Gabriel, S., Silverman, E. S., \& Weiss, S. T. (2005). Polymorphisms in signal transducer and activator of transcription 3 and lung function in asthma. Respiratory Research, 6(1), 52. http://dx.doi. org/10.1186/1465-9921-6-52. PMid:15935090.

Liu, B., He, Z., Wang, J., Xin, Z., Wang, J., Li, F., \& Fu, Y. (2018). Taraxasterol inhibits LPS-induced inflammatory response in BV2 microglia cells by activating LXRa. Frontiers in Pharmacology, 9, 278. http://dx.doi.org/10.3389/fphar.2018.00278. PMid:29670526.

Liu, J., Xiong, H., Cheng, Y., Cui, C., Zhang, X., Xu, L., \& Zhang, X. (2013). Effects of taraxasterol on ovalbumin-induced allergic asthma in mice. Journal of Ethnopharmacology, 148(3), 787-793. http:// dx.doi.org/10.1016/j.jep.2013.05.006. PMid:23727181.

Nishihara-Fujihara, M., Shoji, S., Maeda, I., Shimoda, T., Nishima, S. \& Okamoto, K. (2010). Involvement of fibronectin and matrix metalloproteinases in airway smooth muscle cell migration for the process of airway remodeling. Allergology International, 59(3), 267-275. http://dx.doi.org/10.2332/allergolint.09-OA-0153. PMid:20495339.

Quante, T., Ng, Y. C., Ramsay, E. E., Henness, S., Allen, J. C., Parmentier, J., Ge, Q., \& Ammit, A. J. (2008). Corticosteroids reduce IL-6 in ASM cells via up-regulation of MKP-1. American Journal of Respiratory Cell and Molecular Biology, 39(2), 208-217. http://dx.doi.org/10.1165/ rcmb.2007-0014OC. PMid:18314542.

Redhu, N. S., Shan, L., Alsubait, D., Ashdown, H. L., Movassagh, H., Lamkhioued, B., \& Gounni, A. S. (2013). IgE induces proliferation in human airway smooth muscle cells: role of MAPK and STAT3 pathways. Allergy, Asthma, and Clinical Immunology, 9(1), 41. http:// dx.doi.org/10.1186/1710-1492-9-41. PMid:24499258.

Roberts, C. R., \& Burke, A. K. (1998). Remodelling of the extracellular matrix in asthma: proteoglycan synthesis and degradation. Canadian Respiratory Journal, 5(1), 48-50. PMid:9556512.

Sandford, A. J., Weir, T. D., \& Paré, P. (1998). Phenotypic heterogeneity in asthma and allergy. Clinical and Experimental Allergy, 28(Suppl 1), 26-36. PMid:9641588.

Simeone-Penney, M. C., Severgnini, M., Tu, P., Homer, R. J., Mariani, T. J., Cohn, L., \& Simon, A. R. (2007). Airway epithelial STAT3 is required for allergic inflammation in a murine model of asthma. Journal of Immunology, 178(10), 6191-6199. http://dx.doi.org/10.4049/ jimmunol.178.10.6191. PMid:17475846.

Tang, J., \& Luo, L. (2018). MicroRNA-20b-5p inhibits platelet-derived growth factor-induced proliferation of human fetal airway smooth muscle cells by targeting signal transducer and activator of transcription 3. Biomedicine and Pharmacotherapy, 102, 34-40. http://dx.doi. org/10.1016/j.biopha.2018.03.015. PMid:29549727.

Toop, L. J. (1985). Active approach to recognising asthma in general practice. British Medical Journal, 290(6482), 1629-1631. http://dx.doi. org/10.1136/bmj.290.6482.1629. PMid:3924198.

Wang, S., Wang, Y., Liu, X., Guan, L., Yu, L., \& Zhang, X. (2016). Antiinflammatory and anti-arthritic effects of taraxasterol on adjuvantinduced arthritis in rats. Journal of Ethnopharmacology, 187, 42-48. http://dx.doi.org/10.1016/j.jep.2016.04.031. PMid:27109342.

Wei, D., Le, X., Zheng, L., Wang, L., Frey, J. A., Gao, A. C., Peng, Z., Huang, S., Xiong, H. Q., Abbruzzese, J. L., \& Xie, K. (2003). Stat3 activation regulates the expression of vascular endothelial growth factor and human pancreatic cancer angiogenesis and metastasis. Oncogene, 22(3), 319-329. http://dx.doi.org/10.1038/sj.onc.1206122. PMid:12545153.

Willems-Widyastuti, A., Vanaudenaerde, B. M., Vos, R., Dilisen, E., Verleden, S. E., Vleeschauwer, S., Vaneylen, A., Mooi, W. J., Boer, W., Sharma, H. S., \& Verleden, G. M. (2013). Azithromycin attenuates fibroblast growth factors induced vascular endothelial growth factor via p38MAPK signaling in human airway smooth muscle cells. Cell Biochemistry and Biophysics, 67(2), 331-339. http://dx.doi. org/10.1007/s12013-011-9331-0. PMid:22205500.

Zhu, S., Zhu, J., Zhou, Z., Xi, E., Wang, R., \& Zhang, Y. (2015). TGF- $\beta 1$ induces human aortic vascular smooth muscle cell phenotype switch through PI3K/AKT/ID2 signaling. American Journal of Translational Research, 7(12), 2764-2774. PMid:26885273. 